\title{
THE EFFECT OF DIETARY $\beta$-GLUCANS SUPPLEMENTS ON THE HAEMATOLOGICAL PARAMETERS OF THE SEA TROUT
}

\author{
Olga Revina ${ }^{1,2}$, Vjačeslavs Revins ${ }^{1}$, Dina Cīrule ${ }^{1}$, Anda Valdovska ${ }^{2}$ \\ ${ }^{1}$ Institute of Food Safety, Animal Health and Environment 'BIOR', Latvia \\ ${ }^{2}$ Latvia University of Life Sciences and Technologies, Latvia \\ olga.revina@bior.lv
}

\begin{abstract}
In recent years, the effective immunostimulating properties of $\beta$-glucans have been widely proven not only in mammals, but also in aquatic animals. The aim of this study was to determine the effect of dietary $\beta$-glucan supplements on the percentage of individual types of leukocytes and the haematocrit of the sea trout (Salmo trutta L.). Investigations were performed at the state fish farm 'Tome', hatchery 'Pelči' of the Institute of Food Safety, Animal Health and Environment 'BIOR', during a six month period (September 2018 - February 2019). On the basis of feeding with immunostimulant diets, a total of 15000 sea trout were assigned into five groups. For blood collection healthy fish were randomly selected once a month, five 5 individuals from each group. Blood smears were made to determine the leukocyte differential count. Sampling was done once a month (September 2018 - January 2019) $(n=125)$. Haematocrit was determined by the standard microhaematocrit method. Sampling was done once a month (January 2019 - February 2019) $(n=50)$. We concluded that the dietary $\beta$-glucan supplements can improve the haematocrit level and effect the percentage of individual types of leukocytes of the sea trout, stimulation of the preparation for parr-smolt transformation.
\end{abstract}

Key words: Sea trout, $\beta$-glucans, haematology, leukocytes, haematocrit.

\section{Introduction}

In the last few years, indiscriminate abuse use of antibiotics to prevent and treat bacterial diseases has induced the emergence of several resistant pathogens in aquaculture. Therefore, it is necessary to select suitable ways to control outbreaks of diseases (Vivekanandhan et al., 2002; Meena et al., 2013) as soon as possible. Natural immunostimulants are one of the options to improve resistance to disease in fish and enhance immune response at time of stress (Meena et al., 2013; Vallejos-Vidal et al., 2016; Thompson, 2017).

$\beta$-glucans, especially derived from the cell of baker's yeast Saccharomyces cerevisiae are the most commonly used immunostimulants in aquaculture (Thompson, 2017). Beta-glucans are carbohydrates consisting of linked glucose molecules, which are naturally occurring in the cell walls of cereals, bacteria, fungi with significantly differing macromolecular structure depending on the source (Volman et al., 2008). Betaglucans can increase the innate defence mechanisms of fish by enhancing phagocytic, antimicrobial and cytotoxic functions of macrophages and leukocytes (Cárdenas-Reyna et al., 2017; Thompson, 2017), increased complement and lysozyme activity, and enhanced antibody response (Thompson, 2017).

The biological product 'BGN-2' used in this study (BGN-2) has been developed by 'JP Biotechnology' (Latvia) using our own patented technological process. BGN-2 mainly consists of Saccharomyces cerevisiae yeast derivatives obtained in the process of production of ethanol from grain. It contains two main biologically active components: free $\beta$-glucans and nucleotides. Along with free $\beta$-glucans and nucleotides BGN-2 contains amino acids, peptides and polypeptides, as well as free mannan and $\mathrm{B}$ vitamins.
For many decades the sea trout (Salmo trutta L.) have been reared in Latvia to improve natural salmonid sources (Birzaks, 2014; Rutkovska \& Medne, 2018). According to data from International council for the Exploration of the Sea (International council for the Exploration of the Sea, 2018) total number of reared sea trout smolts released in the Baltic Sea in 2017 was 3804000 . Latvia released 224000 sea trout smolts in 2017, somewhat less than in 2016 (308 000), but more than the last ten-year average (168 000).

Researchers have showed that immunostimulation with $\beta$-glucans can be used to improve growth of the Baltic salmon (Salmo salar) under industrial conditions in Latvia (Medne \& Savicka, 2003), but there is no data about the influence to the haematological parameters of sea trout, namely percentage of individual types of leukocytes and the haematocrit. The aim of this study is to determine the effect of dietary $\beta$-glucan supplements on the percentage of individual types of leukocytes and the haematocrit of the sea trout.

\section{Materials and Methods \\ Experimental fish and husbandry}

Investigations were performed at the state fish farm 'Tome', hatchery 'Pelči' of the Institute of Food Safety, Animal Health and Environment 'BIOR'. Fish hatchery 'Pelči' is located in the drainage basins of the river Venta, Latvia (565' $16.3^{\circ}$ "N 21 $\left.{ }^{\circ} 58^{\prime} 28.6^{\prime \prime} \mathrm{E}\right)$. At the farming trial 15000 farmed sea trout juveniles were randomly distributed into five $1.8 \mathrm{~m}^{3}$ tanks $\left(\mathrm{n}=3000\right.$ in each tank), containing $1.2 \mathrm{~m}^{3}$ of water in flow-through rearing system.

The average initial body weight of the sea trout was $2.3 \pm 0.30 \mathrm{~g}$ 
Fish were allowed to acclimate to the new housing conditions for 14 days. Health of the fish was regularly assessed. Careful netting and handling were implemented to minimize stress.

Fish diet and preparation of feed

The fish were fed commercial feed without supplements prior to the start of the trial.

Fish diet consisted of pelleted commercial feed mixed with two different quantities of $\beta$-glucans (Angel Yeast, China) and two different quantities of BGN-2, administered 20 times a day by the automatic fish feeder at approximately $2 \%$ of body weight per day. The control feed was $\beta$-glucan-free.

Commercial feed was thoroughly mixed with $\beta$-glucan supplement powder and rapeseed (Brassica napus) oil. The pellets were dried in a ventilated room for $1 \mathrm{~h}$ and then placed in the fish feeder. Diets were prepared shortly in advance and were distributed over a 4 day period. Every four days a new diet was prepared in order to ensure freshness and quality.

The five feeding diet groups were:

(1) Fish $(n=3000)$ controls were represented by commercial pellets and $20 \mathrm{~mL}$ rapeseed oil (control group);

(2) Fish $(n=3000)$ fed a mix composed of $1 \mathrm{~g}$ of $\beta$-glucans in $1 \mathrm{~kg}$ of commercial pellets and 20 $\mathrm{mL}$ rapeseed oil ( $1 \mathrm{~g} \mathrm{~kg}^{-1} \beta$-glucans);

(3) Fish $(n=3000)$ fed mix composed of $3 \mathrm{~g}$ of $\beta$-glucans in $1 \mathrm{~kg}$ of commercial pellets and 20 $\mathrm{mL}$ rapeseed oil (3 $\mathrm{g} \mathrm{kg}^{-1} \beta$-glucans);

(4) Fish $(n=3000)$ fed mix composed of $6 \mathrm{~g}$ of BGN-2 in $1 \mathrm{~kg}$ of commercial pellets and $20 \mathrm{~mL}$ rapeseed oil (6 $\left.\mathrm{g} \mathrm{kg}^{-1} \mathrm{BGN}-2\right)$;

(5) Fish $(\mathrm{n}=3000)$ fed mix composed of $14 \mathrm{~g}$ of BGN-2 in $1 \mathrm{~kg}$ of commercial pellets and $20 \mathrm{~mL}$ rapeseed oil (14 $\left.\mathrm{g} \mathrm{kg}^{-1} \mathrm{BGN}-2\right)$.

Blood collection, cell staining and microscopy

For blood sample collection healthy fish were randomly selected once a month $(\mathrm{n}=5$ individuals from each group), from September 2018 to January 2019 for blood smears $(n=125)$ and from January 2019 to February 2019 for hematocrit $(n=50)$. Blood samples were collected from the caudal vein of fish with a heparinized syringe (according to the Republic of Latvia Cabinet Regulation No. 1, adopted 8 January 2019, Regulation of the Protection of Animals Used for Scientific Purposes).

Blood smears were made to determine the leukocyte differential count. Blood smears were stained with MGG Quick Stain (Bio-Optica, Milano) according to manufacturer's instructions. This method of manually determining leukocyte differential count was selected because nucleated red blood cells (RBC) prevent accurate enumeration using automated analysis (Hrubec, Cardinale, \& Smith, 2000). The following cell types were identified: lymphocytes, neutrophils, monocytes, eosinophils and basophils (Lehmann \& Sturenberg, 1981; Изергина, Изергин, \& Изергин, 2014).

Microscopic examination of blood smears was carried out using a light microscope BRESSER TFM$201 / 301$ Science Infinity at magnification $400 \times$ and $1000 \times$ and counting 100 - 200 leukocytes (Изергина, Изергин, \& Изергин, 2014).

Haematocrit or packed cell volume was determined by the standard microhaematocrit method and expressed in percentage. Blood samples were loaded into standard capillary tubes, spun in a microhaematocrit centrifuge for $5 \mathrm{~min}$ and measured on a microcapillary reader. Due to the small size of fish, the haematocrit was taken starting from January, as it was not possible to collect enough blood for analysis.

\section{Statistical analysis}

For statistical analysis of all obtained data Microsoft Office 365 MS Excel was used. Haematological values are represented by means \pm standard error (SE). The significance was determined by the t-test; $p$ value $<0.05$ was used to estimate the level of statistical significance for differences.

\section{Results and Discussion}

Differential leukocyte counts were characterized by predominance of lymphocytes (Table 1). Three types of leukocytes, namely lymphocytes, neutrophils and eosinophils were identified in the circulating blood of sea trout. The differential leukocyte count, like other haematological characteristics, is dependent on the fish species, age, sex, the cycle of sexual maturity, season of the year, different methods of rearing, feed quality, pathogens and stress and health condition (Modra, Svobodova, \& Kolafova, 1998; Ivanc et al., 2005; ReyVázquez \& Guerrero, 2007; Lone et al., 2012; Fazio, 2019). Also, the study of fish leukocytes plays an important role in monitoring of water pollution (Modra, Svobodova, \& Kolafova, 1998). Haematological parameters are important characteristics of the physiological status of fish (Fazio, 2019), but the analyses are not widely used in fish medicine due to the lack of reference intervals (Modra, Svobodova, \& Kolafova, 1998; Barcellos et al., 2003; Lone et al., 2012).

Dietary $\beta$-glucan supplements are a potential immunostimulant for fish (Petit \& Wiegertjes, 2016) thought to affect the number of circulating leukocytes (Baunly et al., 1996); however, according to our study, it did not affect leukocyte differential count significantly. There was no statistically significant difference between the groups with supplements compared to the control group (Table 1), but significant differences were observed in level of neutrophils (diet $3 \mathrm{~g} \mathrm{~kg}^{-1} \beta$-glucans) and eosinophils (diet $1 \mathrm{~g} \mathrm{~kg}^{-1}$ 


\section{Peripheral blood leukocyte differential counts from sea trout}

\begin{tabular}{|c|c|c|c|c|c|}
\hline Parameters & September & October & November & December & January \\
\hline \multicolumn{6}{|c|}{ Control group } \\
\hline Lymphocytes (\%) & $97.3 \pm 1.20^{\mathrm{a}}$ & $92.0 \pm 2.31^{\mathrm{a}}$ & $93.7 \pm 2.31^{\mathrm{a}}$ & $92.3 \pm 2.60^{\mathrm{a}}$ & $97.3 \pm 2.85^{\mathrm{a}}$ \\
\hline Neutrophils (\%) & $2.7 \pm 1.20^{\mathrm{a}}$ & $7.7 \pm 2.03^{\mathrm{a}}$ & $5.7 \pm 2.19^{\mathrm{a}}$ & $7.3 \pm 1.20^{\mathrm{a}}$ & $2.7 \pm 0.88^{\mathrm{a}}$ \\
\hline Eosinophils (\%) & $0.0 \pm 0.00^{\mathrm{a}}$ & $0.3 \pm 0.33^{\mathrm{a}}$ & $0.7 \pm 0.67^{\mathrm{a}}$ & $0.3 \pm 0.33^{\mathrm{a}}$ & $0.0 \pm 0.00^{\mathrm{a}}$ \\
\hline \multicolumn{6}{|c|}{ Diet $1 \mathrm{~g} \mathrm{~kg}^{-1} \beta$-glucans } \\
\hline Lymphocytes (\%) & $97.0 \pm 1.53^{\mathrm{a}}$ & $97.7 \pm 1.45^{\mathrm{a}}$ & $96.0 \pm 0.67^{\mathrm{a}}$ & $99.0 \pm 0.67^{\mathrm{a}}$ & $98.7 \pm 1.15^{\mathrm{a}}$ \\
\hline Neutrophils (\%) & $2.7 \pm 1.20^{\mathrm{a}}$ & $2.3 \pm 1.45^{\mathrm{a}}$ & $3.7 \pm 0.88^{\mathrm{a}}$ & $1.0 \pm 0.58^{\mathrm{a}}$ & $1.3 \pm 0.33^{\mathrm{b}}$ \\
\hline Eosinophils (\%) & $0.3 \pm 0.33^{\mathrm{a}}$ & $0.0 \pm 0.00^{\mathrm{a}}$ & $0.3 \pm 0.33^{\mathrm{a}}$ & $0.0 \pm 0.00^{\mathrm{a}}$ & $0.0 \pm 0.00^{\mathrm{a}}$ \\
\hline \multicolumn{6}{|c|}{ Diet $3 \mathrm{~g} \mathrm{~kg}^{-1} \beta$-glucans } \\
\hline Lymphocytes (\%) & $96.0 \pm 2.08^{\mathrm{a}}$ & $92.0 \pm 2.08^{\mathrm{a}}$ & $97.0 \pm 2.96^{\mathrm{a}}$ & $85.7 \pm 1.20^{\mathrm{a}}$ & $95.3 \pm 2.52^{\mathrm{a}}$ \\
\hline Neutrophils (\%) & $4.0 \pm 2.08^{\mathrm{a}}$ & $7.3 \pm 2.19^{\mathrm{a}}$ & $3.0 \pm 2.52^{\mathrm{a}}$ & $13.7 \pm 0.67^{\mathrm{a}}$ & $4.0 \pm 0.58^{\mathrm{a}}$ \\
\hline Eosinophils (\%) & $0.0 \pm 0.00^{\mathrm{a}}$ & $0.7 \pm 0.33^{\mathrm{a}}$ & $0.0 \pm 0.00^{\mathrm{a}}$ & $0.7 \pm 0.67^{\mathrm{a}}$ & $0.7 \pm 0.67^{\mathrm{b}}$ \\
\hline \multicolumn{6}{|c|}{ Diet $6 \mathrm{~g} \mathrm{~kg}^{-1} \mathrm{BGN}-2$} \\
\hline Lymphocytes (\%) & $93.7 \pm 0.88^{\mathrm{a}}$ & $98.7 \pm 0.67^{\mathrm{a}}$ & $98.3 \pm 0.67^{\mathrm{a}}$ & $96.0 \pm 0.33^{\mathrm{a}}$ & $94.3 \pm 0.33^{\mathrm{a}}$ \\
\hline Neutrophils (\%) & $6.0 \pm 1.00^{\mathrm{a}}$ & $1.3 \pm 0.67^{\mathrm{a}}$ & $1.7 \pm 0.33^{\mathrm{a}}$ & $4.0 \pm 1.15^{\mathrm{a}}$ & $5.7 \pm 1.45^{\mathrm{a}}$ \\
\hline Eosinophils (\%) & $0.3 \pm 0.33^{\mathrm{a}}$ & $0.0 \pm 0.00^{\mathrm{a}}$ & $0.0 \pm 0.00^{\mathrm{a}}$ & $0.0 \pm 0.00^{\mathrm{a}}$ & $0.0 \pm 0.00^{\mathrm{a}}$ \\
\hline \multicolumn{6}{|c|}{ Diet $14 \mathrm{~g} \mathrm{~kg}^{-1} \mathrm{BGN}-2$} \\
\hline Lymphocytes (\%) & $95.0 \pm 1.73^{\mathrm{a}}$ & $93.3 \pm 2.33^{\mathrm{a}}$ & $94.3 \pm 2.33^{\mathrm{a}}$ & $97.3 \pm 2.03^{\mathrm{a}}$ & $94.7 \pm 1.76^{\mathrm{a}}$ \\
\hline Neutrophils (\%) & $4.7 \pm 1.76^{\mathrm{a}}$ & $6.3 \pm 2.19^{\mathrm{a}}$ & $5.7 \pm 1.76^{\mathrm{a}}$ & $2.7 \pm 1.45^{\mathrm{a}}$ & $5.3 \pm 0.88^{\mathrm{a}}$ \\
\hline Eosinophils (\%) & $0.3 \pm 0.33^{\mathrm{a}}$ & $0.3 \pm 0.33^{\mathrm{a}}$ & $0.0 \pm 0.00^{\mathrm{a}}$ & $0.0 \pm 0.00^{\mathrm{a}}$ & $0.0 \pm 0.00^{\mathrm{a}}$ \\
\hline
\end{tabular}

$\mathrm{a}$ and $\mathrm{b}$ means in the same row with different letters are significantly different $(\mathrm{p}<0.05)$

$\beta$-glucans) compared to the other diet groups at the end of experiment.

The highest percentage of lymphocytes was found in the $1 \mathrm{~g} \mathrm{~kg}^{-1} \beta$-glucans group $99.0 \pm 0.67$ in December, also high percentage was observed in January $(98.7 \pm 1.15)$. The lowest percentages of lymphocytes were found in the $3 \mathrm{~g} \mathrm{~kg}^{-1} \beta$-glucans group in December and October $(85.7 \pm 1.20$ and $92.0 \pm 2.08$, respectively).

The highest percentage of neutrophils $(13.7 \pm 0.67)$ was found in the $3 \mathrm{~g} \mathrm{~kg}^{-1} \beta$-glucans group in December whereas the lowest value was in the $1 \mathrm{~g} \mathrm{~kg}^{-1} \beta$-glucans group in December, and it was $1.0 \pm 0.58$.

At the end of the experiment (in January) we observed that the percentage of lymphocytes and neutrophils changed in the $6 \mathrm{~g} \mathrm{~kg}^{-1}$ BGN-2 group (94.3 \pm 0.33 and $5.7 \pm 1.45)$ and in the $14 \mathrm{~g} \mathrm{~kg}^{-1}$ BGN-2 group $(94.7 \pm 1.76$ and $5.3 \pm 0.88)$ compared to other groups. The percentage of neutrophils became higher, but it was lower for lymphocytes. This indicates that the fish begin preparing for parr-smolt transformation (Изергина, Изергин, \& Изергин, 2014). Researchers have reported a similar pattern in the Atlantic salmon parr (Pettersen et al., 2005).
Eosinophils were sporadic in all groups during all the feeding period, with the highest mean value of $0.7 \pm 0.67$ found in the $3 \mathrm{~g} \mathrm{~kg}^{-1} \beta$-glucans in October, December and January. Also, in the control group high percentage of eosinophils was detected once in November, when it was $0.7 \pm 0.67$.

Basophils and monocytes were not found in any of the fish examined. It has also been reported that no basophils have been found in salmonids (Modra, Svobodova, \& Kolafova, 1998; Rutkovska \& Medne, 2012). Also, there is evidence that monocytes, basophilic and eosinophilic granulocytes very occasionally occur in the head kidney and in peripheral blood of rainbow trout (Oncorhynchus mykiss) (Lehmann \& Sturenberg, 1981).

Haematological parameters such as haematocrit, haemoglobin, number of erythrocytes and white blood cells are indicators in toxicity studies on aquatic animals (Barcellos et al., 2003). Mean haematocrit level (Table 2) was found significantly increased in January in the $6 \mathrm{~g} \mathrm{~kg}^{-1}$ BGN-2 and $14 \mathrm{~g} \mathrm{~kg}^{-1}$ BGN-2 groups compared to the control group $-33.8 \pm 5.25$ and $33.0 \pm 5.00$. The highest haematocrit level was observed in February in $6 \mathrm{~g} \mathrm{~kg}^{-1}$ BGN-2 group, but the 


\section{The peripheral blood haematocrit}

\begin{tabular}{|l|c|c|c|c|c|}
\hline & Control group & $1 \mathrm{~g} \mathrm{~kg}^{-1} \beta$-glucans & $3 \mathrm{~g} \mathrm{~kg}^{-1} \beta$-glucans & $6 \mathrm{~g} \mathrm{~kg}^{-1} B G N-2$ & $14 \mathrm{~g} \mathrm{~kg}^{-1} B G N-2$ \\
\hline January & $27.8 \pm 6.20^{\mathrm{a}}$ & $26.5 \pm 3.50^{\mathrm{a}}$ & $30.1 \pm 3.95^{\mathrm{a}}$ & $33.8 \pm 5.25^{\mathrm{b}}$ & $33.0 \pm 5.00^{\mathrm{b}}$ \\
\hline February & $31.5 \pm 2.09^{\mathrm{a}}$ & $29.6 \pm 5.40^{\mathrm{a}}$ & $30.6 \pm 5.50^{\mathrm{a}}$ & $34.9 \pm 3.45^{\mathrm{a}}$ & $29.8 \pm 2.09^{\mathrm{a}}$ \\
\hline
\end{tabular}

$\mathrm{a}$ and $\mathrm{b}$ means in the same row with different letters are significantly different $(\mathrm{p}<0.05)$

lowest percentages were found in January in the $1 \mathrm{~g}$ $\mathrm{kg}^{-1} \beta$-glucans group.

From our point of view, the $\beta$-glucans provide stability and integrity of the haematological parameters of sea trout and thus protect them during stressful conditions. The better haematological alterations appeared for sea trout fed the $6 \mathrm{~g} \mathrm{~kg}^{-1} \mathrm{BGN}-2$ diet, when fish showed an increase in the haematocrit and in the number of neutrophils, which probably represent the activation of protective mechanisms. at $6 \mathrm{~g} \mathrm{~kg}^{-1}$ ) would be beneficial for sea trout, resulting in an increase in the main haematological parameters and stimulation of the preparation for parr-smolt transformation.

\section{Acknowledgements}

The present study was supported financially by the research project 'Strengthening Scientific Capacity of LLU' No. Z-27, The application of Beta-glucan to ensure of sea trout health.

\section{Conclusions}

Present results corroborate that dietary supplementation with $\beta$-glucans (specifically BGN-2

\section{References}

1. Barcellos, L.J.G., Kreutz, L.C., Rodrigues, L.B., Fioreze, I., Quevedo, R.M., Cericato, L., Conrad, J., Soso, A.B., Fagundes, M., Lacerda, L.A., \& Terra, S. (2003). Haematological and biochemical characteristics of male jundia' (Rhamdia quelen Quoy \& Gaimard Pimelodidae): changes after acute stress. Aquaculture Research. 34, 1465-1469.

2. Baulny, M.O., Quentel, C., Fournier, V., \& Lamour, F. (1996). Effect of long term oral administration of Beta-glucan as an immunostimulant or an adjuvant on some non-specific parameters of the immune response of Turbot Scophthalmus maximus. Diseases of Aquatic Organisms. 26(2), 139-147. DOI: $10.3354 /$ dao026139.

3. Birzaks, J. (2014). Latvijas upju ihtiofauna (Ichthyofauna of the Latvian rivers). Latvian Fisheries Yearbook 2014) (pp. 52-59). Latvia: The Latvian Rural Advisory and Training Centre. (in Latvian)

4. Cárdenas-Reyna, T., Angulo, C., Guluarte, C., Hori-Oshima, S., \& Reyes-Becerril, M. (2017). In vitro immunostimulatory potential of fungal $\beta$-glucans in pacific red snapper (Lutjanus peru) cells. Developmental \& Comparative Immunology. 77, 350-358. DOI: 10.1016/j.dci.2017.09.003.

5. Fazio, F. (2019). Fish hematology analysis as an important tool of aquaculture: A review. Aquaculture. 500, 237-242. DOI: 10.1016/j.aquaculture.2018.10.030.

6. Hrubec, T.C., Cardinale, J.L., \& Smith, S.A. (2000). Hematology and Plasma Chemistry Reference Intervals for Cultured Tilapia (Oreochromis Hybrid). Veterinary Clinical Pathology. 29(1), 7-12.

7. International council for the Exploration of the Sea. 2018. Report of the Baltic Salmon and Trout Assessment Working Group (WGBAST), 20-28 March 2018. (2018). Turku, Finland: ICES.

8. Ivanc, A., Haskovic, E., Jeremic, S., \& Dekic, R. (2005). Hematological evaluation of welfare and health of fish. Praxis veterinaria. 53(3), 191-202.

9. Lehmann, J., \& Sturenberg, F.J. (1981). Hematological-serological substrate studies of rainbow trout. Description and preparation of the most important cell types at the site of hematopoiesis and in the peripheral blood vessel system. Burlington, Ontario: Department of Fisheries and Oceans.

10. Lone, G.N., Shammi, Q.J., Mir, S.A., Sheikh, I.A., \& Chalkoo, S.R. (2012). Rainbow Trout Hematology Coinciding with Metabolic Requirement. Walailak Journal of Science and Technology. 9(4), 309-316.

11. Medne, R., \& Savicka, I. (2003). Promotion of salmon rearing efficiency by including yeast extract Aqualase Two in the diet. Acta Universitatis Latviensis. 662, 45-50.

12. Meena, D.K., Das, P., Kumar, S., Mandal, S.C., Prusty, A.K., Singh, S.K., Akhtar, M.S, Behera, B.K., Kumar, K., Pal, A.K., \& Mukherjee, S.C. (2013). Beta-glucan: an ideal immunostimulant in aquaculture (a review). Fish Physiology and Biochemistry. 39(3), 431-457. DOI: 10.1007/s10695-012-9710-5. 
13. Modra, H., Svobodova, Z., \& Kolafova, J. (1998). Comparison of Differential Leukocyte Counts in Fish of Economic and Indicator Importance. Acta vet. Brno. 67, 215-226.

14. Petit, J., \& Wiegertjes, G.F. (2016). Long-lived effects of administering $\beta$-glucans: Indications for trained immunity in fish. Developmental \& Comparative Immunology. 64, 93-102. DOI: 10.1016/j. dci.2016.03.003.

15. Pettersen, E.F., Bjørløw, I., Hagland, T.J., \& Wergeland, H.I. (2005). Effect of seawater temperature on leucocyte populations in Atlantic salmon post-smolts. Veterinary Immunology and Immunopathology. 106, 65-76. DOI: 10.1016/j.vetimm.2005.01.001.

16. ReyVázquez, G., \& Guerrero, G.A. (2007). Characterization of blood cells and hematological parameters in Cichlasoma dimerus (Teleostei, Perciformes). Tissue Cell. 39(3), 151-60. DOI: 10.1016/j.tice.2007.02.004.

17. Rutkovska, I., \& Medne, R. (2012). Hematological parameters of one year old sea trout (Salmo trutta) in spring. In urrent events in veterinary research and practice, 22-23 November 2012 (pp. 131-135). Jelgava, Latvia.

18. Rutkovska, I., \& Medne, R. (2018). Triiodothyronine and thyroxine changes in yearling sea trout (Salmo trutta L.) during spring. Fisheries \& Aquatic Life. Archives of Polish Fisheries. 26, 101-109. DOI: 10.2478/ aopf-2018-0011.

19. Thompson, K.D. (2017). Immunology: Improvement of Innate and Adaptive Immunity. In G. Jeney (Eds.), Fish Diseases. Prevention and control Strategies (pp. 3-20). United Kingdom: Academic Press.

20. Vallejos-Vidal, E., Reyes-López, F., Teles, M., \& MacKenzie, S. (2016). The response of fish to immunostimulant diet. Fish \& Shellfish Immunology. 56, 34-69. DOI: 10.1016/j.fsi.2016.06.028.

21. Vivekanandhan, G., Savithamani, K., Hatha, A.A.M., \& Lakshmanaperumalsamy, P. (2002). Antibiotic resistance of Aeromonas hydrophila isolated from marketed fish and prawn of South India. International Journal of Food Microbiology. 76, 165-168. DOI: 10.1016/S0168-1605(02)00009-0.

22. Volman, J.J., Ramakers, J.D., \& Plat, J. (2008). Dietary modulation of immune function by $\beta$-glucans. Physiology \& Behavior. 94(2), 276-284. DOI: 10.1016/j.physbeh.2007.11.045.

23. Изергина, Е.Е., Изергин, И.Л., \& Изергин, Л.И. (2014). Атлас клеток крови лососевых рыб материкового побережья северной части Охотского моря (Atlas of blood cells of salmonids on the continental coast of the northern part of the Sea of Okhotsk). Магадан: Кордис. (in Russian) 